\title{
A fluorescence lidar for seamlessly connecting individual observations of the global environmental systems (Erratum)
}

Y. Saito, T. Tomida, K. Shiraishi

Y. Saito, T. Tomida, K. Shiraishi, "A fluorescence lidar for seamlessly connecting individual observations of the global environmental systems (Erratum)," Proc. SPIE 10779, Lidar Remote Sensing for Environmental Monitoring XVI, 1077914 (10 July 2019); doi: 10.1117/12.2542562

Event: SPIE Asia-Pacific Remote Sensing, 2018, Honolulu, Hawaii, United States 


\section{A fluorescence lidar for seamlessly connecting individual observations of the global environmental systems (Enatum)}

Y. Saito, T. Tomida, Shinshu Univ. (J apan), K. Shiraishi Fukuoka Univ. (Japan)

Proceedings Volume 10779, Lidar Remote Sensing for Environmental Monitoring XVI; 107790M

(2018) https://doi.org/10.1117/12.2324428

Event: SPIE Asia-Pac ific Remote Sensing, 2018, Honolulu, Ha waii, United Sta tes

Online Publication Date: 24 Oc to ber 2018

Enatum Published: 10 J uly 2019

A revised version of this ma nuscript was published on 10 July 2019. Deta ils of the revision a re provided in the text that accompa nies this Erratum. The original paper has been updated.

\section{Revisions:}

Figure $4(\mathrm{a})$, the labels on the $\mathrm{x}$ and $\mathrm{y}$ axes were reversed:

24 October 2018 version: x axis: "Exc itation wa velength ( $\mathrm{nm})$ "

y axis: "Emission (fluoresc ence) wavelength $(\mathrm{nm})$ "

10 J uly 2019 Version: xaxis: "Emission (fluorescence) wa velength (nm)"

y a xis: "Excitation wavelength (nm)" 